\title{
The Gospel of Thomas
}

\author{
By APRIL D. DeCONICK
}

Isla Carroll and Percy E. Turner Professor of Biblical Studies, Rice University

This article views the Gospel of Thomas as the product of an early Eastern form of Christianity, most probably originating in a Syrian context. The text should not be seen as representing some Gnostic or marginal sapiential form of Christianity, rather it reflects a trajectory in 'orthodox'

Christianity that valued mystical or esoteric teaching. Such traditions have been found in mainstream Christianity throughout its history. The text of the Gospel of Thomas is understood to be a rolling corpus, or aggregate of sayings that represent different moments in the life and history of the early Thomasine community.

\section{KEYWORDS}

Gospel of Thomas, Gnosticism, Community Memory, Rolling Corpus, early Syrian Christianity, Mysticism

If there is one early Christian gospel that has a career both famous and infamous, it is the Gospel of Thomas. It has been called a 'direct and almost unbroken continuation of Jesus' own teaching - unparalleled anywhere in the canonical tradition' ${ }^{1}$ - as well as a 'perversion of Christianity by those who wanted to create Jesus in their own image'. ${ }^{2}$ It has been understood as an early Jewish Christian document, preserving independent Jesus traditions older than the New Testament gospels, as well as a late Gnostic gospel entirely dependent on the canonical gospels. On the one hand it has been lauded as the 'fifth gospel', while on the other it has been dismissed as 'heretical'. What are we to make of this enigmatic gospel containing 114 known and unknown sayings of Jesus?

\section{Discovery of the Gospel of Thomas}

The Gospel of Thomas was found in 1945 near Nag Hammadi, Egypt. The story of its discovery was eventually traced in 1975 by a young American scholar of the New Testament and early Christianity, James Robinson, when he personally followed up a lead recorded in Arabic in the acquisitions log of the Coptic Museum in Cairo, a lead which stated that seventy leaves of an ancient Christian Coptic manuscript were purchased by the Museum for 250 pounds from Raghib Andarawus on 4th October $1946 .^{3}$

The story that Robinson recovered is quite fantastic, even legendary now. It all started with a young peasant by the name of Muhammad Ali and his two brothers who were searching near the village Hamrah Dum for fertilizer to use on their crops and fuel their family's cooking fires.

\footnotetext{
${ }^{1}$ H. Koester, 'GNOMAI DIAPHOROI', in Trajectories through Early Christianity (edited by James M. Robinson and Helmut Koester; Philadelphia, PA: Fortress Press, 1971), 139.

${ }^{2}$ Robert Grant and David Noel Freedman, The Secret Sayings of Jesus: The Gnostic movement which challenged Christianity and its 'Gospel of Thomas' recently discovered in Egypt (Garden City, NY: Doubleday, 1960$), 20$.

3 John Dart, The Jesus of Heresy and History: The Discovery and Meaning of the Nag Hammadi Gnostic Library (San Francisco, CA: HarperSanFrancisco, 1988), 1-49.
} 
Muhammad's brother, Khalifah, dug up a large clay pot. At first Muhammad Ali was afraid to open the pot, for fear that a jinn, an evil spirit, might reside in the old pot. But curiosity and lust for coins took the better of him and he regained his courage and smashed open the jar. When his mallet broke the pot, tiny bits of golden particles littered the air, papyrus fragments floating away on the wind like flakes of snow. Inside the jar was a cache of old leather books. He gathered them up and took them home. When he arrived in his yard, he dumped the papyri books on the ground next to his mother's baking oven. His mother later confessed to Robinson that she used the torn books and covers to start the fires to bake her bread! ${ }^{4}$

The books found their way into the hands of various antiquities dealers and private individuals, including Carl Gustav Jung, after whom the Jung Codex is named. Eventually, all of the books were tracked down and gathered by the Egyptian authorities. By the late 1950s, all came to be housed together in the Coptic Museum in Old Cairo.

UNESCO assembled an international team of scholars to photograph the manuscripts and publish a facsimile edition. The team was also responsible for transcribing, translating and publishing the books as quickly as possible. Robinson led the team. The first English translation of the entire Nag Hammadi collection was published in 1979, thirty-four years after the original find. In 1988, a completely revised edition of the translation was made available to the public. In total, there are thirteen separate books containing forty previously unknown texts from the early Christian period, literature written almost 2,000 years ago and lost for the last 1,600 years. The Gospel of Thomas is among them, written in Coptic as are the rest of the texts in the collection.

Early transcription work on the Gospel of Thomas made clear that another papyrus hoard from Oxyrhynchus, Egypt in the 1890s was related to the Gospel of Thomas. ${ }^{5}$ In the late 1800s, Bernard Grenfell and Arthur Hunt from Oxford University had excavated one of the chief centres of early Christianity in Egypt, the city of Oxyrhynchus. It is located about 120 miles south of Cairo on the edge of the desert. They unearthed the old town dump where they found scores of papyri, mainly in Greek, which had been discarded with the rubbish. The papyri they found dated from the first to the eighth century, and embraced every subject that one might expect to find discussed by the inhabitants of a flourishing Roman city.

There was quite an enthusiastic reaction in the academic world to the original publication by Grenfell and Hunt of the 'lost sayings' of Jesus preserved by P.Oxy. 1, 654 and 655. It wasn't until 1952 that the French scholar Henri-Charles Puech made the connection between these fragments and the Coptic Gospel of Thomas found at Nag Hammadi. ${ }^{6}$ While in Cairo with Gilles Quispel examining some of the Nag Hammadi texts gathered at the Coptic Museum, he realized that the Oxyrhnychus fragments were pieces of the Gospel of Thomas. This was quite significant because it meant that the Coptic was a translation from an earlier Greek version of the Gospel,

\footnotetext{
4 James M. Robinson, Nag Hammadi Library in English (San Francisco, CA: Harper, 1988), 22-25.

${ }^{5}$ B. P. Grenfell and A. S. Hunt, Sayings of Our Lord from an Early Greek Papyrus (London: The Egypt Exploration Fund, 1897); B. P. Grenfell and A. S. Hunt, New Sayings of Jesus and Fragment of a Lost Gospel from Oxyrhynchus (London: The Egypt Exploration Fund, 1904).

${ }^{6}$ H.-Ch. Puech, 'Une Collection de Paroles de Jésus Récemment Retrouvée: L'Évangile selon Thomas', Comptes rendus des séances - Academie des inscriptions \& belles-lettres (1957), 146-66.
} 
and since one of the Greek papyri had been dated to $200 \mathrm{CE}$, this meant that there was manuscript evidence of this Gospel 150 years older than the Coptic. However, since Grenfell and Hunt had argued from internal evidence that the original composition of this Greek fragment could be dated to the late first or early second century (no later than $140 \mathrm{CE}$ ), suddenly the Gospel of Thomas became very interesting to scholars of early Christianity. A gospel containing lost sayings of Jesus could be contemporary with some of the writings that ended up in the New Testament.

\section{Initial Scholarly Interpretations of the Gospel of Thomas}

\subsection{Old Jewish Christian Gospel}

Professors Quispel and Puech had been invited to the Coptic Museum in the early 1950s by the successor to Toga Mina as the Museum's director, Pahor Labib. Together, they examined the Nag Hammadi manuscripts and began to form an initial opinion about the Gospel of Thomas - its provenance and theology. Quispel, in his first publications on the Gospel in the late 1950s, was convinced that the Gospel of Thomas was based on an old lost gospel that had been used by Jewish Christians, either the Gospel of the Hebrews or the Gospel of the Nazoraeans. ${ }^{7}$ He argued that the sayings in the Gospel of Thomas have no literary connection with our Greek New Testament Gospels, but represent an independent early tradition of sayings associated with James the leader of the Jerusalem Church and probably known in Aramaic. This appeared reasonable given the linguistic work that Antoine Guillaumont had been doing on the Gospel of Thomas. ${ }^{8}$ Guillaumont had joined Quispel in his study of the text as they prepared with three other colleagues the first English translation of the Gospel. Guillaumont's linguistic analysis of the Coptic in commentary-like articles he published in the late 1950s had been building the case for an Aramaic or Syriac substratum for the Thomasine sayings. Although Quispel referred to some linguistic arguments, the main case he made for his position came from his training as a Source Critic - he tried to determine the earliest literary sources upon which the Gospel of Thomas was based. He attempted to do so by identifying sayings in the Gospel of Thomas that had reasonable - but not exact - parallels in other extra-canonical gospel documents.

\subsection{Late Gnostic Gospel}

By the early 1960s, however, scholars weren't absolutely convinced by Quispel's theory, mainly because his arguments relied on fragmentary evidence from Jewish Christian Gospels composed in Greek, not Aramaic. The versions of the sayings and the thematic parallels he identified in the

\footnotetext{
${ }^{7}$ Gilles Quispel, 'The Gospel of Thomas and the New Testament', VC 11 (1957), 189-207; 'Some Remarks on the Gospel of Thomas', NTS 5 (1958/1959), 276-90; 'L'Évangile selon Thomas et les Clémentines', VC 12 (1958), 181196; 'L'Évangile selon Thomas et le Diatesssaron', VC 13 (1959), 87-117; 'The “Gospel of Thomas" and the "Gospel of the Hebrews"', NTS 12 (1966), 371-82; 'The Gospel of Thomas Revisited', Colloque International sur les Textes de Nag Hammadi. Québec, 22-25 août 1978, BCNH 1 (ed. B. Barc; Québec, 1981), 218-66.

${ }^{8}$ A. Guillaumont, 'Sémitismes dans les logia de Jésus retrouvés à Nag-Hammâdi', JA 246 (1958), 113-23;A. Guillamont, 'Les 'Logia' d'Oxyrhynchus sont-ils traduits du copte?', Mus 73 (1960), 325-33; A. Guillaumont, 'NHSTEUEIN TON KOSMON (P.Oxy. 1, verso, 1.5-6)', BIFAO 61 (1962), 15-23; A. Guillamont, 'Les sémitismes dans I'Évangile selon Thomas: Essai de classement', in R. van den Broek and M. J. Vermaseren (eds.), Studies in Gnosticism and Hellenistic Religions presented to Gilles Quispel on the Occasion of his 65th Birthday, EPRO 91 (Leiden: E. J. Brill, 1981), 190-204.
} 
Jewish Christian sources varied enough from their parallels in the Gospel of Thomas to posit some doubt in the minds of most scholars at the time. So scholars turned to a more colourful, even exotic explanation, developing the opinion that the Gospel of Thomas was a Gnostic Gospel and therefore late and literarily dependent on our New Testament Gospels.

Scholars who first thought that the Gospel of Thomas was a Gnostic Gospel set out to prove that it belonged to a specific Gnostic group by comparing sayings found in the Gospel with information that we have about certain Gnostics preserved in the writings of the Church Fathers and Bishops of the early Church. The two most influential scholarly opinions were that it was written by either a Naassene Gnostic ${ }^{9}$ or a Valentinian Gnostic. ${ }^{10}$ These theories were worked out by several international scholars in the early 1960s including Grant, Freedman, Schoedel, Smyth, Cornélis, Cerfaux, Garitte, and Gärtner. Once it was recognized, however, that the theology of the Gospel of Thomas did not conform to either Naasene or Valentinian forms of Gnosticism, scholars tried another angle. Could the Gospel of Thomas represent a generic form of Gnostic religiosity? This question was asked by scholars such as Wilson, Bauer, Roques, Montefiore, Vielhauer, Schrage, Säve-Söderbergh, Ménard, and Haenchen. If so, perhaps the Gospel represented the premier example of an ancient religion which scholars called 'Gnosticism', a relatively modern term coined to describe an ancient possibility. Scholars went so far as suggesting that the very existence of 'Gnosticism' was proven by the existence of the Gospel of Thomas, a circular argument if ever there was one! This interpretation of the Gospel of Thomas became standard (and dismissive of the Gospel) even though no scholar could account for the fact that the text does not even hint at the demise of Sophia or point to the role of the Demiurge. If the text were truly Gnostic, why did it not refer in any way to unique features or terminology characteristic of Gnostic mythology?

\subsection{A Proto-Gnostic Gospel}

To account for the Gnostic 'silence' in the Gospel of Thomas, some scholars started to think of this Gospel as a 'precursor' to what they began to call 'full-blown' Gnosticism. It was a text in transition, on its way to becoming a Gnostic Gospel, but not-quite-there-yet. The champions of this highly influential position were Helmut Koester and James Robinson (and later their students, including Steven Patterson, Marvin Meyer, Ron Cameron and Phil Sellew) whose works systematically explore the connection between the proverbial tradition and the Gospel of Thomas.

\footnotetext{
${ }^{9}$ The opinion that the Gospel of Thomas emerged out of Naasene Gnosticism was developed by several international scholars in a variety of early publications: Robert Grant, 'Notes on the Gospel of Thomas', Vigilae Christianae 13 (1959), 170-80; Robert Grant and David Noel Freedman, The Secret Sayings of Jesus: The Gnostic Movement which Challenged Christianity and its 'Gospel of Thomas' Recently Discovered in Egypt (Garden City, NY: Doubleday, 1960); William Schoedel, 'Naasene Themes in the Coptic Gospel of Thomas', Vigilae Christianae 14 (1960), 225-34; Kevin Smyth, 'Gnosticism in 'The Gospel according to Thomas',' Heythrop Journal 1 (1960), 18998; E. Cornélis, 'Quelques elements pour une comparison entre l’Évangile de Thomas et la notice d'Hippolyte sur les Naassènes', Vigilae Christianae 15 (1961), 83-104.

${ }^{10}$ The origins of the Gospel of Thomas in the Valentinian Gnostic tradition was pioneered by three scholars: L. Cerfaux and G. Garitte, 'Les paraboles du Royaume dans L'Évangile de Thomas', Muséon 70 (1957), 307-27; Bertil Gärtner, The Theology of the Gospel of Thomas (translated from the Swedish original by Eric J. Sharpe; London: Collins, 1961).
} 
According to this school of thought, the Gospel of Thomas was a Gnostic gospel, not in the sense of a fully-mature Gnostic system, but in some proto-Gnostic sense. However, it was not dependent on the New Testament or composed late because the genre of the Gospel of Thomas was earlier and more primitive than the New Testament gospels. ${ }^{11}$ The Gospel of Thomas did not develop out of an interest in evangelizing Jesus' passion and resurrection. So it does not represent the latest end of the written gospel trajectory with its interest in recording a narrative about Jesus' death and its salvific agenda. Rather, from the perspective of genre, it is a collection of sayings very similar to the earlier written sources that the authors of the New Testament gospels relied on when they created their narratives about Jesus' ministry and death. It has affinities with Q.

Koester recognized several different types or 'forms' of sayings in Q and the Gospel of Thomas. Present were sayings in the form of pronouncements on legal issues, prophetic sayings, blessings and curses, parables and apocalyptic sayings. But it was the proverbs or 'wisdom sayings' sayings that are admonitions from a teacher and general expressions of truth - he focused on, arguing that they determined the nature of this collection of sayings. ${ }^{12}$

This study led Koester to argue that the Gospel of Thomas presents Jesus not as a prophet, but as a sage who speaks with the authority of the heavenly Sophia. Through his words, Jesus grants salvation to those who hear his words and understand them. ${ }^{13} \mathrm{He}$ admonishes people to recognize themselves, particularly their inner divinity and destiny, in order to overcome death. The Kingdom, far from being a future end-of-the-world or 'eschatological' experience, is present in the person of Jesus and the believer. Renunciation of the world is preached, along with liberation of the soul from the body.

But what about the large number of sayings found in the Gospel of Thomas that appear much more esoteric than the proverbial system can account for? In the Gospel of Thomas, Jesus does not simply teach 'everyday' wisdom to the common folk. He is characterized as a 'living' mystagogue, a hierophant, teaching 'hidden sayings' and 'mysteries' to a chosen few. Koester said that this 'spiritualization' of the wisdom sayings - when the author goes beyond the traditional usages of Jewish proverbs to Gnostic conceptions - is a 'natural progression' towards Gnosticism, an idea dependent on the research of Robinson. ${ }^{14}$

If it were the case that the Gospel of Thomas is a collection of proto-Gnostic sayings, then they cannot represent early Christian traditions. Or could they? Koester insisted that, even though Thomas' sayings are 'Gnostic' as they are preserved in this Gospel, there is still an 'almost unbroken continuation of Jesus' own teaching' taking place, a continuity 'unparalleled anywhere in the canonical tradition'. ${ }^{15}$ He noted that, when compared with variants of the sayings in the New Testament Gospels, the versions of the sayings in the Gospel of Thomas often lacked

\footnotetext{
${ }^{11}$ Robinson and Koester, Trajectories, 158-204.

${ }^{12}$ Koester refers to examples in Gos. Thom. of general truths $(31,32,33.34,35,45,47,67,94)$ and admonitions $(26,39,92,93)$.

${ }^{13}$ Helmut Koester, Introduction to the New Testament: History and Literature of Early Christianity (vol. 2; Walter de Gruyter: Berlin, 2nd edn, 2000), 154-58.

${ }^{14}$ Robinson and Koester, Trajectories, 71-113.

${ }^{15}$ Robinson and Koester, Trajectories, 139.
} 
secondary interpretations and developments. This led him to conclude that the author of the Gospel of Thomas probably had access to a very old collection of Jesus' sayings, a collection that also was incorporated into Q. So Thomas contained sayings that predated our earliest source for the New Testament Gospels, Q.

It is this unresolved tension between 'primitive tradition' and 'Gnosticism' that complicates his theory. He seems to be aware of this, admitting that the 'natural' progression makes it difficult to sort out what sayings belong to the 'original composition' and what are 'later additions'. But even so, he goes on to argue that it is quite likely that an early version of the Gospel of Thomas was composed around the year $50 \mathrm{ce}$, in the area of Palestine or Syria, since a few of the sayings from this Gospel and its 'wisdom theology' are known to the Corinthian community. ${ }^{16}$

If the sayings in the Gospel of Thomas represent very early versions of the words of Jesus when compared with their parallels in the New Testament Gospels, how did they compare with Q? Koester noticed one striking difference. All the sayings in Q which speak about the so-called 'Son of Man' were absent from the Gospel of Thomas. Koester concluded from this that the Gospel was based on a collection of sayings older than Q, before Jesus was identified with the Son of Man.

This meant to him that the non-apocalyptic sayings in the Gospel of Thomas represented an early version of Christianity in which Jesus appears as a wise sage whose words bring salvation to the believer. This version of Christianity did not know about the Cross, nor an interpretation of Jesus' death steeped in atonement ideology, nor did it anticipate the imminent End of the world. It was a form of Christianity unaware of traditional theology and based authentically on Jesus' own message. He thought that Thomas' gospel developed these original sayings of Jesus along a Gnostic trajectory, while Q developed along an apocalyptic one.

Koester's assessment of Q and the Gospel of Thomas has worried more than a few scholars. One of the most vocal, perhaps, has been James Dunn. He said in response to Koester's theory, 'I do not think that the apocalyptic elements of Jesus' teachings can be sloughed off quite so readily', because ' $Q$ is almost certainly earlier and nearer to Jesus' emphasis than any non-apocalyptic version of the Jesus-tradition'. More to the point, he noted that a large number of sayings in the Gospel of Thomas look much more like 'de-eschatologized tradition rather than pre-apocalyptic tradition'. 17

Another factor in some scholars' resistance to Koester's position, has been his uncritical reliance on Robinson's identification of the 'sayings of the wise' genre. Although Robinson's 'trajectory' might represent a possible development of sayings traditions in the case of the Gnostic Gospel of Philip or Pistis Sophia, it certainly does not represent the 'only' or the 'natural' one. In the case of the Dialogue of the Saviour and the Book of Thomas the Athlete, the sayings traditions are reused in an encratic context, a context honouring the celibate lifestyle at the expense of the married. The Teachings of Silvanus and the Sentences of Sextus show a continued interest in the

\footnotetext{
161 Corinthians $1-4$.

${ }^{17}$ Dunn refers to sayings 1, 3, 8, 11, 19, 21, 35, 37, 51, 59, 76, 103, 109, 111, 113. James Dunn, Unity and Diversity in the New Testament: An Inquiry Into the Character of Earliest Christianity (Philadelphia, PA: Westminster Press, 1977), 286.
} 
sayings genre among the 'orthodox' Christians in Alexandria, who recycle the sayings for their own purposes.

So some scholars began emerging in the late seventies and eighties who have been reluctant to describe the Gospel of Thomas in terms of proto-Gnosticism. Stevan Davies explored the theology of the Gospel as an expression of the Jewish wisdom tradition with no reference to Gnostic thought. ${ }^{18}$ The French Sister and pupil of Jacques Ménard, Margaretha Lelyveld, alternatively found that the Gospel of Thomas is not a proverbial or Gnostic collection at all. ${ }^{19}$ Rather it is an oracular collection of prophetic sayings that opens in terms similar to Deuteronomy, 'These are the words that Moses spoke to all Israel' ${ }^{20}$ Because oracular collections include prophetic sayings, apocalyptic pronouncements, legal rulings, and so forth, this appeared to her to allow for a better genre comparison with the Gospel of Thomas than a proverbial collection alone allows.

I myself deeply question scholars' continued reliance on proto-Gnostic or Gnostic traditions to explain the esotericism in the Gospel of Thomas, precisely because there is no distinctive feature of Gnostic mentality to be found among these sayings. I also am deeply concerned that scholars so easily jump to locate esotericism outside of mainstream Christianity, labelling it dismissively 'heretical' or 'gnostic', as if esotericism cannot be found within 'orthodoxy' as well. The impulse toward mysticism is very strong in early Judaism and Christianity - I would even argue 'foundational'. ${ }^{21}$ It is this form of religiosity that I myself turn to in order to explain the esotericism preserved within the Gospel of Thomas. ${ }^{22}$ I think that such an interpretative move is necessary to carry us beyond the Gnostic stalemate to a more historically astute perspective.

\section{Compositional History of the Gospel of Thomas}

If we have any chance of rediscovering the meaning of the Gospel of Thomas, we must first solve the great mystery of its history. Where did it come from? How did it come into its present form? Why did it develop the way it did? These questions may seem to have easy and obvious answers. Did someone not sit down with a pen in hand and write it, perhaps relying on written sources like the New Testament Gospels? This type of answer reveals the enormous distance between ourselves and ancient people, between our world of information technology and their world of memory and story. Their culture was one dominated by memory and orality, punctuated only by occasions of reading and writing.

\subsection{Oral Consciousness and Rhetorical Culture}

\footnotetext{
${ }^{18}$ Stevan L. Davies, The Gospel of Thomas and Christian Wisdom (New York: The Seabury Press, 1983).

${ }^{19}$ Margaretha Lelyveld, Les Logia de la Vie dans L'Évangile selon Thomas (Nag Hammadi Studies 34; Leiden: Brill, 1987), 5, 134-35.

${ }^{20}$ Deuteronomy 1:1.

${ }^{21}$ April D. DeConick, 'What is Early Jewish and Christian Mysticism?', in Paradise Now: Essays on Early Jewish and Christian Mysticism (edited by April D. DeConick; Symposium 11; Atlanta, GA: Society of Biblical Literature, 2006), $1-24$.

${ }^{22}$ April D. DeConick, Seek To See Him: Ascent and Vision Mysticism in the Gospel of Thomas (VC Supplement 33; Leiden: Brill, 1996).
} 
For the most part people in the ancient world did not know how to read or write, nor did they have ready access to people who could read and write. What they knew, they knew because they had heard it from someone, and what they could teach, they taught by retelling it from their memories. This means that when we are trying to understand the transmission of traditions among the first Christians, we are dealing for the most part with oral mentalities, not a process imagined by us in familiar literary terms. Even the process of writing was approached by those who were literate from the perspective of an oral consciousness rather than the literate consciousness that dominates our culture today. Like literacy which has its own mentality, orality has its own consciousness. It is an organic consciousness with distinct tendencies.

What are these tendencies? We are fortunate enough to have the results of studies conducted by folklorists and anthropologists in the early 1900s, at a time when there existed pocket cultures whose consciousness was dominated by orality. From these studies as well as more recent ones, we can begin to see how the oral world was characterized by markedly different presuppositions and thought patterns from our own. ${ }^{23}$ Oral thought is commonly aggregative, adding details and new material to the base information. Oral thought provokes redundancy in a way that writing does not, since the orator frequently repeats parts of his story and cannot go back and erase. Oral thought demands a reliance on memory with little to no dependence on external sources of information. Oral thought is controlled by its situation, who the audience is, what they wish to hear, how long they might remain, who might interrupt, what questions might be posed, and so on. Oral thought is dynamic, fluid and plastic in ways that written texts are not.

One can imagine what this meant practically for the early Christians. An orator might have stood in front of a crowd and began to speak from his own memory of Jesus, or from his memory of what he had heard about Jesus. The moment of his oration was the moment of composition, when he provided the listeners with his own understanding of the traditional material he had learned from Jesus or some other teacher. This oration would never have reproduced the 'original' story or speech because he would not have memorized it 'word for word' in the sense that we literates understand the 'word'. Ong, an expert on orality, has explained that the way verbal memory works is very different from what literate people imagine. In a literate culture, we memorize words verbatim by referring to a text as often as possible to perfect and test our mastery. ${ }^{24}$ This was not the case among peoples controlled by oral mentalities.

Does this mean that the orator or performer was completely free with the traditions and could remake them in any way he chose? Absolutely not. Kenneth Bailey has studied orality in modern

\footnotetext{
${ }^{23}$ M. Parry, The Making of Homeric Verse: The Collected Papers of Milman Perry, ed. by A. Parry (Oxford, 1971); A. Lord, Singer of Tales, HSCL 24 (Cambridge: Harvard University Press, 2nd edn, 2000); E. A. Havelock, Preface to Plato (Cambridge, 1963); W. J. Ong, Orality and Literacy (New York: Routledge, 1982, 2000); W. J. Ong, The Presence of the Word (New Haven, 1967); W. J. Ong, Rhetoric, Romance, and Technology; E. A. Havelock, Origins of Western Literacy, The Ontario Institute for Studies in Education, Monograph Series 14 (Toronto, 1976); K. O'BrienO'Keeffe, Visible Song: Transitional Literacy in Old English Verse, Cambridge Studies in Anglo-Saxon England 4 (Cambridge: Cambridge University Press, 1990); J. M. Foley, Immanent Art: From Structure to Meaning in Traditional Oral Epic (Bloomington: Indiana University, 1991); J. M. Foley, The Singer of Tales in Performance (Bloomington, IN: Indiana University, 1995).

${ }^{24}$ Ong, Orality and Literacy, 57-58.
} 
Middle Eastern villages for over twenty years. ${ }^{25}$ He found that certain types of traditions have more flexibility in their retelling than others. Poems and proverbs had very little room for adjustment and were retained conservatively in the tradition. Parables and narratives had more room for play, while jokes and casual news the most. He unequivocally found that the audience acts as a 'control' for the performer so that the traditions do not become unpredictable or disconnected from the community's memory and experience.

\subsection{Communal Memory}

The community's control on its repository of traditions highlights for us the communal nature of traditions, that the ideas, stories, sayings, texts, rituals, myths, creeds, liturgies, and so on, are attached to specific groups of people, in specific locations and regions. This observation helps to check any faulty impression that ancient texts represent the imagination and opinions of an isolated author, when they more likely represent the communal memory of living religious groups of people. ${ }^{26}$

Understanding the tendencies of communal memory is essential to understanding how and why the ancient Christians passed on and recorded information in the ways they did. Social memory, or communal memory as I prefer to call it, is the dimension of remembering that we share in common with each other. It is a group's 'remembered history', transcending the individual person. ${ }^{27}$ It is dependent on shared frames of reference within a culture, and makes little sense outside these frames.

One of the most important tendencies we must understand regarding the nature of communal memory is that the memory of the group is not a factual recounting of previous events or ideas. The formation of communal memory is not a simple matter of the retrieval of past traditions and history. Sociologists and anthropologists have demonstrated again and again that the memory of the group is dominated, even controlled, by the present experience of the group. This means that the past is remade into memories with contemporaneous meaning. It is the group that attributes significance to certain details from its past. It is the group that is responsible for continually renewing and reviving the memories of the community's origins and other landmark events in its history. Each community actually weaves together what Yael Zerubavel calls its 'master commemorative narrative' which each new generation realigns with its own present experiences. $^{28}$

Here we circle back to Bailey's observation that the community really controls the adaptation of the tradition, not the individual performer. It is the community that keeps the memories of its past from being invented out of nothing or grossly distorted by a contemporary whim or ideology. True, its memories are emerging out of the past in the contemporary moment, but this

\footnotetext{
${ }^{25}$ K. Bailey, 'Informal Controlled Oral Tradition and the Synoptic Gospels', AsiaJT 5 (1991), 34-54; K. Bailey, 'Middle Eastern Oral Tradition and the Synoptic Gospels', ExpTim 106 (1995), 363-67.

${ }^{26}$ For a good introduction to social memory theory, seeB. Zelizer, 'Reading the Past Against the Grain', Critical Studies in Mass Communication 12 (1995), 214-39.

${ }^{27}$ B. Lewis, History: Remembered, Recovered, Invented (Princeton, NJ: Princeton University Press, 1975$), 11-12$.

${ }^{28}$ Y. Zerubavel, Recovered Roots: Collective Memory and the Making of Israeli National Tradition (Chicago, IL: University of Chicago, 1997), 4, 7.
} 
does not mean that the orator or performer can do anything he wishes with his material. At the same time, issues like historical accuracy or authenticity are accommodated to other issues of community concern, be it social identity, political authority, religious orthodoxy and so forth.

\subsection{A Rolling Corpus}

So what comes to the forefront for us is not the question of how accurately a collection like the Gospel of Thomas depicts what Jesus actually said, but why a particular group of Christians constructed its memories in this particular way at some particular time. That the sayings were preserved at all in written format is highly significant and is connected to the group's desire to retain and retrieve its memory. This means that written texts like the Gospel of Thomas served as memory aids which were used by the community as permanent sites for the storage and future dissemination of its contents.

So the Gospel of Thomas emerges as a written document under the weight of its past and the needs of the community to make sense of changing historical circumstances. The Gospel we have represents a long history of transmission, perhaps 'beginning' as a simple written gospel of some of Jesus' sayings. As new needs arose in the community, is it not plausible that additional sayings would have accumulated in this collection in order to address these needs? As new converts joined the community, is it not reasonable that they would have brought with them new ideas and interpretations? As the Christians in this community welcomed wandering preachers, is it not likely that they would have learned 'new' Jesus sayings from them, and added these to their gospel performances?

If this is the case (and I think it very probable), it would mean that the sayings in the Gospel of Thomas represent different moments in its history and might be read as memoirs of practices and conflicts that arose over time within the community. An aggregate text like this likely would have been the result of its recitation and explication during community gatherings when the written sayings of Jesus were orally re-performed probably as homilies or instructions for proselytes. We can imagine that the developing traditions were re-scribed at crucial moments in the history of the community, when members feared the loss of their traditions or when pressure within the group demanded significant reinterpretation. The version of the Gospel of Thomas that we have before us would represent a scribing of one of these later recitations, or a memory of it.

So the text we possess is an aggregate text, a text that accumulated traditions and their interpretations over time. It began as an old core, or as I call it, a Kernel gospel, which was expanded to include new sayings and opinions that worked to align the new experiences of the community with its remembrance of its past. This expansion would not have been a conscious rewriting of the old traditions, as if a Christian sat down one day with a pen in hand and added new sayings and erased others, but a result of the community's memory seamlessly adapting their past to make sense of the present, mainly (although not exclusively) within the field of oral performance. 
So the Gospel of Thomas is a 'rolling' book, ${ }^{29}$ containing memories of the words of Jesus over the entire life of the community until such a time when the book began to be considered 'sacred' and preserved by copyists, instead of orators who had enjoyed more flexibility with the 'text'.

\section{Theological Perspectives in the Gospel of Thomas}

Of course, a big question emerged in the course of my own study of the Gospel of Thomas from this compositional perspective. ${ }^{30}$ How is it possible to distinguish earlier Kernel sayings from later ones that may have accrued during a later performance of the Kernel Gospel? How can we identify and separate the later accretions from the earlier traditional material?

The starting point for me is the identification and examination of sayings where we see obvious signs of secondary development: when interpretative clauses have been appended to older sentences; when sayings have been reshaped into rhetorical question-and-answer units; and when retrospective dialogues have reclaimed older sayings. Once these accretive units are identified, they can be examined in order to further identify vocabulary and themes characteristic of the accretive material. Only after the characteristic vocabulary and themes have been demarcated can they be used to expose additional accretions by searching the remaining sayings for coherence to the cited vocabulary and themes. The remaining sayings are determined to be the oldest, the sayings which likely were part of the original Kernel. ${ }^{31}$

An analysis of the Kernel sayings reveals a speech gospel that is quite old. It appears to have contained five speeches of Jesus and has affinities with Q. The contents of the speeches point to their origin in the Jerusalem mission prior to $50 \mathrm{CE}$. All five speeches are organized around the imminence of the eschaton, emphasizing how urgent the time is, how near judgement, and what this means to discipleship, exclusivity to Jesus and his cause, and the inaugurated Kingdom. The Christology in the Kernel is strikingly early, pre-dating even Q. In the Kernel, Jesus is God's Prophet who exclusively speaks God's truth. He is also thought to be an exalted Angel of Judgement, casting fire upon the earth and selecting the faithful from the unfaithful for the Kingdom.

All of these descriptors are commonly associated with the theology of early Christian Judaism from Jerusalem, a tradition of Christianity that traveled east and was embedded in later texts written in eastern Syria like the Pseudo-Clementines. I think it worth noting that it is in the Pseudo-Clementine correspondence that we hear that Clement was commissioned by James to write down the words and instructions of the true Prophet as Peter taught them to his audiences. This speech record was to be sent to James for use in proselytizing (Rec. 1.17; 1.21; Hom.

\footnotetext{
${ }^{29}$ A term coined by William McKane to explain the com-positional history of Jeremiah. See W. McKane, A Critical and Exegetical Commentary on Jeremiah (ICC; Edinburgh: T\&T Clark, 1986), xlix-xcix.

${ }^{30}$ This is thoroughly laid out in my two volume work: April D. DeConick, Recovering the Original Gospel of Thomas: A History of the Gospel and its Growth (LNTS 286; London: T\&T Clark, 2005); and April D. DeConick, The Original Gospel of Thomas in Translation, with a Commentary and New English Translation of the Complete Gospel (LNTS 287; London: T\&T Clark, 2006).

${ }^{31}$ For a complete listing of the Kernel sayings and the accretions, see DeConick, Original Gospel of Thomas in Translation, 10. Pages 25-31 contain an English translation of the Kernel, while pages 32-42 contain an English translation of the complete gospel with accretions in italics.
} 
Epistle of Peter to James 2). It is also of great value that it is in the Pseudo-Clementine material that we find the only references to distinctive parallels of sayings from the Kernel. The clusters, sequencing, and hermeneutics of many of these sayings also follow the Kernel rather than the sequencing or interpretation provided by the Synoptics. ${ }^{32}$ This is highly suggestive of a written Kernel known to the author of the Pseudo-Clementines or his sources.

So the original Gospel of Thomas was urgently and imminently eschatological in its orientation, and may provide us with some valuable information about the theology of the Jerusalem church during the 'dark age' of early Christianity, the years 30-50 CE. It appears that this old speech gospel was taken by the missionaries east into Syria where it was left with the Christian community there. Over the years in this new environment, it was adapted to the changing needs, demands and theology of the Christians in Syria. Accretions gradually developed within the collection, working to reconfigure and reinterpret the older sayings and hermeneutics once they became a liability or irrelevant to the present experience of the Syrian Christians. This shift in the gospel can be traced linguistically as well as theologically, since there is evidence for an older Aramaic substratum beneath the Kernel sayings, and a Syriac one beneath the accretions. ${ }^{33}$

The theology of the accretions develops the apocalypticism of the Kernel in the sense that it shifts from the eschatological dimension to the mystical. The main experience (but not the exclusive one!) which led to the reconfiguration of the Kernel was the Non-Event - when the contemporary experience of the Christians in Syria did not match their expectations for world dissolution and Judgement. When the Kingdom did not come, they responded by reinterpreting Jesus' sayings in their small speech book. The external imminent eschaton was collapsed into the internal immanent visio dei. So the accretions describe a mystical form of Christianity in which the believer worked not just to understand God, but to 'know' him in the most immediate and the most direct sense.

For the Christians who reconfigured the gospel, the first step in this mystical transformation was to achieve the body-without-passions. So many of the sayings encourage an encratic praxis, honouring the life of the solitary or single person above all else. These Christians took seriously the call to celibacy, believing that sexual renunciation would serve to recreate their bodies in Adam's image before the Fall (G.Th. 4.1, 4.3, 11.2-4, 16.4, 21.1-4, 21.6-9, 22, 23.2, 27.1, 37, $49,64.12,75,85,101,105,106,110,111.2,114)$. They taught each other that it was necessary to renounce the world, to fast from the world, and to guard against temptations and worldliness (G.Th. 27, 21.6-8, 110). Imitation of Jesus conquering his passions at his crucifixion was encouraged (G.Th. 55, 56, 58, 80, 87, 112). Participation in the eucharist appears to have aided in the person's transformation since the gospel mentions on several occasions the power of divine food and drink to render the person 'equal' to Jesus (G.Th. 13, 61, 108).

Once the body had been conquered and Jesus imitated, the believer was encouraged to study and meditate on the words of Jesus (G.Th. 1). Through this praxis, they sought revelation and vision. This mystical apocalypse included journeys into the heavenly realms to see Jesus (G.Th. 37) and worship before God's throne (G.Th. 15). Knowledge of the passage through the heavenly realms was memorized (G.Th. 50) so that the believer could gaze upon God before death in order not to

\footnotetext{
${ }^{32}$ DeConick, Original Gospel of Thomas in Translation, 242-43.

${ }^{33}$ DeConick, Original Gospel of Thomas in Translation, 11-15, 19-21.
} 
die (G.Th. 59). In heaven, the believer would meet his or her divine twin, the lost image, the true Self (G.Th. 84). The Christians who participated in this praxis believed that the immediate and direct vision of God would result in their full transformation into their original bodies of glory, so that they would no longer 'die'. This praxis results from a fusion of early Jewish mystical traditions about the heavenly Man, the loss of the radiant Image, and its recovery with the Hermetic story about the fallen soul and its recovery through Self-knowledge and vision. It is a praxis that appears to have been developed in tandem and dialogue with Christianity in Alexandria in the late first and early second centuries.

All in all, the accretions tell the story of a Christian community in Syria whose members are no longer waiting for death or the eschaton in order to enter the Kingdom or achieve immortality. Instead of waiting for heaven to come to them, they are invading Eden, sincerely believing that the eschatological promises of God are able to be fulfilled in the present. Their apocalyptic expectations have collapsed, shifting their theology away from hopes of an imminent eschaton to mystical pre-mortem experiences of God. They were already Adam and Eve in Paradise. So the

Non-Event became for them the fulfilment of the Event. Jesus' promise of the imminent End had been actualized within the boundaries of their community.

\section{The Thomasine Community}

This reading of the Gospel of Thomas places it squarely within early orthodoxy rather than outside. The Gospel of Thomas does not represent the voice of some late generic Gnostic heresy or some early unique sapiential Christianity. Rather it is quite cogent with early Syrian Christianity as described in the oldest literature from the area. So any recovery of 'community' is really the recovery of the Christian community in Syria, with the knowledge that the community experienced shifts within its membership during the time that the gospel itself was composed, particularly an increase in Gentile converts and a shift to accommodate their interests (G.Th. 6.1, $14.1-3,14.5,27.2,43,52,53,60)$.

Arthur Vööbus taught us long ago that Christianity in eastern Syria in the first couple of hundreds of years demanded celibacy and asceticism for admission into the Church. The literary evidence from Nag Hammadi, the apocryphal Acts, the Pseudo-Clementines, the records of the Church Fathers, point to a form of Christianity in Syria which was encratic, honouring the solitary life over the marital. The larger catholic Church, particularly in the West, did not favour this position, so our historical memory of these people is that of sectarians and even heretics. But they were neither. For these Christians, baptism followed by daily washings and renunciation of the body extinguished desire and made it possible for them to begin to restore their souls to the glorious Image of God. This position on the solitary life appears to me to have shifted with Aphraates, whose writings show us that the demands of celibacy were eventually relaxed, reserved for the privileged class of the Syrian Church, the 'sons and daughters of the covenant'.

What is the religiosity of our earliest Syrian sources? In this literature, the human being regains a lost Paradise through his or her own effort of righteous living as revealed by Jesus, not through some act of atonement on Jesus' part. Over and over again, through story after story, the Christian is taught that he or she must become as self-controlled as possible, overcoming desire 
and passions that lurk in the soul. He or she is taught through discourse and example that marriage should be abandoned in order to achieve the prelapsarian conditions of 'singleness'. When this is done, gender difference is abolished and the believer can be united with his or her divine double in the 'bridal chamber'. This divine double, the person's new spouse, is in fact Jesus himself. It is Judas Thomas, Judas the Twin, who becomes the metaphor for all believers, since Jesus is described as his very own Twin.

So I am completely convinced that the Gospel of Thomas theologically and practically is an infant of eastern Christianity, particularly as it was practiced in Syria. It is one of our earliest, if not our earliest text showcasing a very old form of 'Orthodox' thought. As such, it is very at home in the Syrian environment and represents old Syrian religiosity. It is a precursor to eastern Orthodoxy, as even a superficial reading of that catechism reveals. Eastern Christianity is about a mysticism of the heart and the progressive transformation of the soul into its glorious Image. In the West, the Augustinian position reigns, so that we know about 'original sin' severing us from our true Image, leaving us lost and helpless and damned. In the West, the lost are saved through grace and atonement which is completed in the eucharist, a sacrificial meal. In the East, the glorious Image is not lost, but only diminished or stunted by Adam's decision. It can be recovered in part through our own orientation and action. In the East, the eucharist is the ingestion of the divine body, aiding the transformation of the soul into the glorious Image. In Orthodoxy, the believer is called to self-knowledge, renunciation of the body through temperance in marriage or the Eremitic life, spiritual warfare and purification of the passions, the path of virtue, imitation of Jesus, and contemplation. This leads to a gradual glorification - a transformation due to 'gnosis' and 'theoria' - and ultimately the Taboric vision of God as light.

The mystical tradition in the Gospel of Thomas is very old, and emerges out of connections with apocalyptic thought. Once the eschatological story did not manifest as expected, these Christians remodelled the familiar sayings of Jesus by shifting their focus to the mystical dimension of Jesus' sayings. The theology that they developed shares the mega-story of the earliest Christianity in Syria, and ultimately should be recognized as an early 'Orthodox' Syrian Gospel.

I think that the 'place' of the Gospel of Thomas within early Christianity has been wrongly identified in the past, but not because it represents a type of Christianity unfamiliar to the canonical tradition or deviant from it. I think it has been wrongly identified for the simple reason that our categories, particularly in regard to mysticism in this period, could not contain it. That Western religiosity has controlled the discourse on this Gospel has not helped matters, since this Western discourse did not possess the conceptual framework to explain it. 


\section{Bibliography}

Davies, S. L., The Gospel of Thomas and Christian Wisdom (New York: The Seabury Press, 1983).

DeConick, A. D., Seek To See Him: Ascent and Vision Mysticism in the Gospel of Thomas (VC Supplement 33; Leiden: Brill, 1996).

DeConick, A. D., Recovering the Original Gospel of Thomas: A History of the Gospel and its Growth (LNTS 286; London: T\&T Clark, 2005).

DeConick, A. D., The Original Gospel of Thomas in Translation, with a Commentary and New English Translation of the Complete Gospel (LNTS 287; London: T\&T Clark, 2006).

Fallon, F. T. and Cameron, R., 'The Gospel of Thomas: A Forschungsbericht and Analysis', ANRW 2:25.6 (New York, 1988), pp. 4195-251.

Grenfell, B. P. and Hunt, A. S., Sayings of Our Lord from an Early Greek Papyrus (London: The Egypt Exploration Fund, 1897).

Grenfell, B. P. and Hunt, A. S., New Sayings of Jesus and Fragment of a Lost Gospel from Oxyrhynchus (London: The Egypt Exploration Fund, 1904).

Layton, B., Nag Hammadi Codex II, 2-7, NHS 20 (Leiden: E. J. Brill, 1989).

Lelyveld, M., Les Logia de la Vie dans L'Évangile selon Thomas (Nag Hammadi Studies 34; Leiden: Brill, 1987).

Ménard, J.-E., L’Évangile selon Thomas, NHS 5 (Leiden: E. J. Brill, 1975).

Meyer, M., The Gospel of Thomas: The Hidden Sayings of Jesus (San Francisco: Harper SanFrancisco, 1992).

Patterson, S., 'The Gospel of Thomas and the Synoptic Tradition: A Forschungsbericht and Critique', FFF 8 (1992), pp. 45-97.

Patterson, S., The Gospel of Thomas and Jesus (Sonoma: Polebridge Press, 1993).

Robinson, J. and Koester, H. (eds.), Trajectories through Early Christianity (Philadelphia, PA: Fortress Press, 1971).

Uro, R. (ed.), Thomas at the Crossroads: Essays on the Gospel of Thomas (Edinburgh: T\&T Clark, 1998).

Uro, R., Thomas. Seeking the Historical Context of the Gospel of Thomas (London: T\&T Clark, 2003). 